Marquette University

e-Publications@Marquette

Theology Faculty Research and Publications

Theology, Department of

6-1-2013

"After All, Africa is Largely a Nonliterate Continent": The Reception of Vatican II in Africa

Agbonkhianmeghe E. Orobator

Marquette University, agbonkhianmeghe.orobator@marquette.edu

Published version. Theological Studies, Vol. 74, No. 2 (June 2013): 284-301. DOI. (C) 2013

Theological Studies, Inc. Used with permission.

Agbonkhianmeghe E. Orobator was affiliated with Hekima College Jesuit School of Theology at the time of publication. 


\title{
"AFTER ALL, AFRICA IS LARGELY A NONLITERATE CONTINENT": THE RECEPTION OF VATICAN II IN AFRICA
}

\author{
Agbonkhianmeghe E. Orobator, S.J.
}

The article examines critical factors that determined the impact, reception, and implementation of Vatican II in Africa. Drawing on historical accounts, the author identifies and analyzes personalities, contexts, and issues that conditioned and shaped Africa's participation in the council. Looking back 50 years, he argues that while the continent's participation was negligible, shaped by a combination of events and attitudes that either facilitated or hampered reception, concrete examples abound of how the council generated impetus for growth, renewal, and reform in inculturation, interreligious dialogue, theological reflection, and ecclesial collaboration in Africa.

$\mathrm{O}$ F AfricA's ROLE in the Second Vatican Council, Patrick Kalilombe, recently deceased theologian and bishop of Lilongwe, Malawi, wrote:

The presence of Africa at Vatican II was marginal and by proxy. . . . Although technically and juridically the Church was no longer 'missionary,' it is hardly possible to imagine that the African Church counted very much as an influence on the Council. Apart from regular interventions from the principal spokesman, Cardinal L. Rugambwa, only sporadic voices were heard from Africa.

It is obvious from an examination of the sixteen documents that the Council was largely a forum for the concerns of the Churches of Europe and America in the 1960 s. ...

Africa's problems and preoccupations, therefore, came only indirectly: they did not determine the central perspective from which the Council's deliberations were moving. . . . Moreover, real acquaintance with the documents must not be exaggerated, even though efforts were made to publish them and diffuse their

Agbonkhianmeghe E. Orobator, S.J., received his $\mathrm{PhD}$ from the University of Leeds and is now provincial superior of the Eastern Africa Province of the Society of Jesus and lecturer in theology at Hekima College Jesuit School of Theology. Concentrating on ecclesiology and ethics, he has recently coedited (with Paterne A. Mombé, S.J., and Danielle Vella), AIDS 30 Years Down the Line: Faith-Based Reflections about the Epidemic in Africa (2012); "The Struggle against Racism and the Global Horizon of Christian Hope," in Ecclesiology and Exclusion: Boundaries of Being and Belonging in Postmodern Times, ed. Dennis M. Doyle et al. (2012); and "Look Back to the Future: Transformative Impulses of Vatican II for African Catholicism," Concilium International Journal of Theology 3 (2012). Forthcoming is a collection entitled "Feminism: Conversations in the World Church," coedited with Linda Hogan. 
message widely in the African continent. . . After all, Africa is largely a nonliterate continent. ${ }^{1}$

\section{THE CONTEXT}

To describe and assess the reception, impact, and implementation of the Second Vatican Council in Africa requires understanding the social and political context of the continent during the period of announcement, convocation, deliberation, and conclusion of the council (1959-1965). Viewed from the perspective of contemporary events in Africa, the council did not happen in a vacuum. "For the Catholic Church in Africa the vast internal revolution set in motion by Pope John more or less coincided with the political and cultural revolution of Independence."2 Vatican II occurred at a momentous time in the history of Africa when nationalist tumult and agitation slowly and intensely rose to a combustible crescendo. During the conciliar years, that movement would culminate in precipitated transfer of political power from bewildered and beleaguered colonialists to exuberant and inexperienced African leaders.

Thus the religious excitement occasioned by the sudden announcement and convocation of the council coincided with the secular excitement over Africa's political emancipation. Symbolically, Pope John XXIII's radical objective of aggiornamento bore notable resemblance to aspirations for political independence in several African countries in the 1960s. In church as in secular society the promise of change and a future of hope struck a deep and optimistic resonance in the hearts and minds of Africans. This parallel movement offers a first clue to the impact of Vatican II in Africa:

Probably in no other continent did the Vatican Council coincide quite so neatly and sympathetically with a major process of secular change as in Africa. . . The conciliar themes of localization and pluralism, of the recognition of the positive values of different cultures and even other religious traditions, the new use of the vernacular in the liturgy, the ecumenical rapprochement, all this conformed with the general early 1960s' stress on African political and cultural values, on decolonization, on the social necessity of cooperation and unity across the division of tribe, race and religion. ${ }^{3}$

${ }^{1}$ Patrick A. Kalilombe, "The Effect of the Council on World Catholicism: Africa," in Modern Catholicism: Vatican II and After, ed. Adrian Hastings (London: SPCK, 1991) 310-18, at 310-11.

2 Adrian Hastings, A History of African Christianity, 1950-1975 (New York: Cambridge University, 1979) 167-68.

3 Adrian Hastings, "The Council Came to Africa," in Vatican II: By Those Who Were There, ed. Alberic Stacpoole (London: Geoffrey Chapman, 1986) 315-23, at $315-16$. 
Yet this correlation of the promise and hope of Vatican II for the church and the wave of sociopolitical change in Africa needs to be critically examined before being adopted as the basis for analyzing and assessing Africa's reception of the council.

For setting this positive evaluation in context, two points are noteworthy. First, we may not overlook the fact that nationalism/independence and the conciliar event represented distinct interests and divergent preoccupations in Africa. Whereas the former interest was orchestrated by mission-bred and mission-educated Africans who hardly distinguished colonial adventure from missionary agenda, the latter interest was led by missionary ecclesiastics and clergy suspicious of the pulsating waves of political emancipation and self-determination. In the aftermath of independence, tension surfaced promptly between the missionary church and nascent political regimes around issues of schools, political system of one-party rule, and an elitist cast of ideologues eager to appropriate the spoils of independence. ${ }^{4}$ Second, Adrian Hastings, to whom is credited these positive impressions of Vatican II in relation to Africa, wrote at a time much closer to the council and, as I will point out in this essay, from the perspective of arguably the most vigorous promoter and advocate of the directives of Vatican II. Much has transpired on the continent since then. Looking back 50 years, the temptation is strong to conclude that just as the promise and hope of political independence failed to deliver progress and development, so too did the aggiornamento of Vatican II become tepid in Africa.

This article examines some of the factors that have conditioned and shaped Africa's reception of Vatican II. It premises this exploration on the thesis that due to a complex interplay of personalities, attitudes, events, and contexts, what was heralded as a radical renewal and change in direction, or an aggiornamento, for the church has progressed along a checkered path on the African continent.

I begin by analyzing three primary factors that were determinant of Africa's role during the sessions of Vatican II. These factors fall under the broad categories of demography, ecclesiology, and theology. Following this analysis, I provide a concise account of the reception and principal achievement of Vatican II for the church in Africa-using appropriate examples-and indicate paths to the future inspired by the spirit of the council.

It is important to concede the spatial limitation of this analysis, focusing as it does primarily on eastern Africa-an option influenced largely by the relative scarcity of materials covering the entire continent of Africa. Besides, considering the characteristic diversity of the continent, any

${ }^{4}$ Hastings, History of African Christianity 151-52. 
account of Vatican II's reception, impact, and implementation would be of necessity partial and offer only a basic overview.

\section{FACTORS INFLUENCING AFRICA'S PARTICIPATION AT VATICAN II}

\section{Counting Bodies and Weighing Voices}

If we proceed from the assumption of the adage that synodus episcoparum est, we could perhaps form a preliminary impression of Vatican II and its impact on ecclesia in Africa. In the first place, African bishops constituted a small percentage of the overall composition of the council. The presence of Africa in terms of representation by so-called native bishops and ecclesial leaders was numerically insignificant. Besides the question of meager representation, an additional focal point of analysis is the influence that this minority had on the proceedings and outcomes of the council. It would not be an exaggeration to contend that none of the African bishops present at Vatican II had a major voice or played a decisive role, a factor routinely attributed to their unpreparedness in regard to the complex themes, documents, and conciliar process. ${ }^{5}$ Those who had a major voice were expatriates either as Council Fathers or as periti. ${ }^{6}$

Historical accounts of Africa's presence and participation at Vatican II identify some of the leading figures that flew the banner of the continent. Expectedly almost all of them were expatriates. One of the leading bishops at Vatican II from Africa was the charismatic and energetic Bishop Joseph

5 Albert de Jong, The Challenge of Vatican II in East Africa: The Contribution of Dutch Missionaries to the Implementation of Vatican II in Tanzania, Kenya, Uganda, and Malawi, 1965-1975 (Nairobi: Paulines, 2004) 28; Hastings, History of African Christianity 168.

${ }^{6}$ It is important to note that African voices at the council raised issues of pertinence to the continent that unfortunately were not reflected in any of the final documents. An example of this was the matter of tribalism and "the feminist cause" reputedly championed at the council by Archbishop Malula of Kinshasa, DRC (formerly Leopoldville, Zaire). See Dennis Hurley, O.M.I., Vatican II: Keeping the Dream Alive (Pietermaritzburg, South Africa: Cluster, 2005) 105-6. On the whole, however, it would seem that the intervention of African bishops was limited to pithy comments and reactions to particular issues. See, e.g., ibid. 108, 109, 129, 138. By far the most active in terms of number of oral interventions and written submissions at the council were Archbishop Dennis Hurley (Durban, South Africa) and the first African cardinal, Laurean Rugambwa (Bukoba, Tanzania). See Philippe Denis, "The Historical Significance of Hurley's Contribution to Vatican II," in Hurley, Vatican II 207-8. That the voices of African bishops at Vatican II had limited impact or influence is further confirmed by the fact that no African bishop appears in John W. O'Malley's list of "Council Participants Frequently Mentioned" (What Happened at Vatican II [Cambridge, MA: Harvard University, 2008] 321-28). 
Blomjous of Mwanza, Tanzania. Alongside was Bishop Vincent McCauley of Fort Portal, Uganda, variously characterized by Richard Gribble as a "driving force," "catalyst," and "spokesman" of the bishops from East Africa. ${ }^{7}$ The insignificant participation of African-born bishops at the council seems confirmed by Dutch church historian Albert de Jong's claim that Dutch bishops ghostwrote the interventions of African bishops. ${ }^{8}$ This claim, however, should not be generalized. Archbishop Denis Hurley's account of events at the council proffers some qualification of De Jong's assertion. While Hurley-himself a leading figure from Africa at the council-received help from some prominent European periti, his intervention reflected his authorship and his untiring appeal for a council that is pastoral in its approach to the issues of the day. ${ }^{9}$ Yet, contrary to Hastings's contention that the participation and contribution of Africa was "not insignificant," 10 the view held by Philippe Denis-and shared by Patrick Kalilombe noted above-is representative of the consensus among scholars regarding the influence of African bishops at Vatican II:

Most observers agree, however, that the African bishops failed significantly to influence the work of the Council itself. The African representation-260 of a total 2,358 at the first session in 1962 — had relatively little weight in the final outcome of the Council. The themes discussed were perceived as "too European" not only by the 61 African-born bishops present at the opening of the Council, but also by the missionary bishops. ${ }^{11}$

Notwithstanding the numerical insignificance and theological unpreparedness of African Council Fathers, the accounts also concur in stressing that the modus operandi of African bishops was well organized and highly efficient during the conciliar sessions. ${ }^{12}$ A minor but highly symbolic fact was the presence of a lay auditor from Togo, Eusebe Adjakpley. ${ }^{13}$

7 Richard Gribble, The Implementation of Vatican II in Eastern Africa: The Contribution of Bishop Vincent McCauley, CSC (Lewiston, NY: Edwin Mellen, 2009) 70,74 .

8 De Jong, Challenge of Vatican II in East Africa 30.

9 Hurley, Vatican II 30, 162-78.

${ }^{10}$ Hastings, History of African Christianity 173.

11 Denis, "Historical Significance of Hurley's Contribution" 197-98.

12 A firsthand account by Hurley corroborates the claim of organizational superiority of African bishops at the council: "The African Bishops had not wasted any time in getting themselves organised. South Africa had taken the lead in regard to the English-speaking African bishops and secured the use of a very convenient hall in a street off the Via della Conciliazione. . . The African bishops got together in two groups, the Anglophone (i.e. English-speaking) and the Francophone (the French-speaking)" (Hurley, Vatican II 23-24; see also O'Malley, What Happened at Vatican II 122).

13 Hurley, Vatican II 139. 


\section{A Church in the Making}

The second factor is ecclesiological. In the early 1960s, the church in Africa could hardly be qualified as "African." As the preceding point demonstrates, in terms of leadership and direction, the church in Africa prior to and during Vatican II represented a native outpost of a Eurocentric ecclesial organization. Understandably, therefore, the concerns of the universal church as outlined and debated at the council barely intersected with the pressing issues that the "young" churches in places like Africa had to contend with. Thus, as the conciliar drama unfolded in the aula, and European and North American ecclesiastical grandees fought running battles across doctrinal and ideological lines, African bishops watched with bemusement and fascination variously as spectators, cheerleaders, and voting bloc. ${ }^{14}$

\section{African Theology en Route}

The third and final point concerns the status of theology in Africa as local production. In the 1960 s, African theology was still in its formative years. At the time of Vatican II the popular debate centered on the desirability, feasibility, and possibility of African theology as a viable discipline. Consequently, at this watershed event, Africa lacked the theological expertise and institutional capacity to engage the pertinent issues on Vatican II's agenda. A telling illustration of this lacuna appears in the composition of the African delegation. Alongside the majority of expatriate bishops the corps of periti was exclusively European and North American. ${ }^{15}$ Unlike "the bishops of the Western European bloc," the council's African contingent did not have "the advantage of this magnificent pool of theologians and also of Scripture scholars, historians, liturgical experts and prominent promoters of lay apostolates, social concern and catechetics." 16 Regrettable as this observation might seem at first sight, closer examination suggests that it contains a positive element in regard to the topic under consideration. It can be plausibly argued that to a large extent the impetus to develop an African theology came from Vatican II: "Vatican II brought to Africa a theology and a catechesis whose central themes showed how the power of Jesus Christ supplanted the power of local gods. This theology became concrete in the church's sacramental system where signs and words expressed initiation, maturity, healing, forgiving, and nourishment."17

14 O'Malley, What Happened at Vatican II 291-95.

15 Hastings, "The Council Came to Africa" 316.

16 Hurley, Vatican II 71-72.

17 Bede Jagoe, "Vatican II Comes to Africa," Worship 79 (2005) 544-54, at 548. 
The factors outlined above provide some evidence of the unpreparedness of the church in Africa for Vatican II. The cadre of ecclesial leadership and, much less, the body of the church in Africa were not prepared for the council.

\section{RECEPTION AND IMPLEMENTATION}

Richard McBrien defines reception as the "process by which the body of the faithful, or a significant portion thereof, accepts and abides by an official teaching or disciplinary decree of the hierarchical Church." ${ }^{18}$ Reception, however, is not a straightforward process; in church history, councils have encountered objection, resistance, and rejection. Historian of church councils Norman Tanner notes that "other major councils, such as Nicea I or Chalcedon, had laboured receptions precisely because of the importance and challenging nature of their teaching. So too with Vatican II."19

As mentioned above, the event of Vatican II paralleled significant historic political events in Africa in the 1960s. The intersection of events held out fresh promise for church and society in Africa. "The fresh new breeze of aggiornamento and the new energy of the political and cultural revolutions in Eastern Africa made Vatican II quite acceptable to the African Church." 20 This assertion calls for a twofold qualification. First, it presupposes a homogeneous and established reality called the "African Church." At the time of the council, such a reality did not exist; at best, it was still in the making. Second, acceptability would have been limited to the hierarchy largely comprised of expatriate missionary bishops and clergy, and not to any recognizable, informed, and active community of African Christians. The general assessment is that in "the rather untheological world of the Catholic Church in Africa," Vatican II had very little impact on the ground, beyond academic circles and hierarchical concerns. ${ }^{21}$ Yet De Jong's contention that Vatican II "formed the starting point for the self-reliance, the inculturation and the renewal of the African Church" 22 is largely correct, if interpreted in a strict sense, that is, as a task that was yet to be fully accomplished rather than as a finished product.

The reception and implementation of Vatican II in Africa can be assessed in the context of a broad set of factors that either facilitated or impeded this process. These factors are not exhaustive. The following represents and illustrates some of the most important considerations.

18 Richard P. McBrien, The Church: The Evolution of Catholicism (New York: HarperOne, 2008) 322.

${ }_{19}^{19}$ Norman Tanner, "How Novel Was Vatican II?" Asian Horizons 6 (2012) 401-10, at 408 .

${ }^{20}$ Gribble, Implementation of Vatican II in Eastern Africa 77.

${ }^{21}$ Hastings, "Council Came to Africa" 317.

${ }^{22}$ De Jong, The Challenge of Vatican II in East Africa 30. 


\section{The Challenge of Literacy}

Vatican II produced a corpus of constitutions, decrees, and declarations of varying themes, degrees of authority, lengths, and styles for dissemination, study, and implementation in the church. "Indeed the texts of Vatican II, in words, amount to twice that of all the first seven councils taken together." ${ }^{, 3}$ For a continent steeped in orality and unremarkable for its literacy levels, this factor constituted a formidable challenge. The texts of Vatican II delivered in high ecclesiastical Latin would have been incomprehensible to the vast majority of African Christians and clergy in the postconciliar years. "The average lay person with no understanding of English had no possibility whatever of reading and studying the Vatican II documents [in Latin]."24

The linguistic challenge was equally true for bishops and priests, as Hastings points out: "The bishops returned to their dioceses with a heap of Latin documents to redirect a clergy far less informed about what had been going on than their counterparts in Europe but also, for the most part, far more willing to be redirected. The laity, of course, were still more uninformed." 25 The clergy (and laity) were as unprepared for the implementation of Vatican II as the latter's documents were inaccessible and incomprehensible. This situation, however, was mitigated by approximations of translation in English and Swahili. ${ }^{26}$

To extend this argument on literacy, from a historical perspective, the reception of Vatican II and the realization (or lack thereof) of its promise in Africa was the result of an absence of a sustained initiative to inform the people of God "on the mind of the Church, as expressed in Vatican II." 27 There is, however, evidence that some bishops created platforms in their dioceses to speak informally about their experiences at Vatican II to a mixed audience of clergy, religious, and lay people. ${ }^{28}$ While this practice would have been common in the postconciliar years, it gradually declined as the excitement of renewal and reform ebbed, and as interest in the study of Vatican II's documents receded to the exclusive domain of seminary formation.

23 Tanner, "How Novel Was Vatican II?" 404.

${ }_{25}$ De Jong, Challenge of Vatican II in East Africa 34.

${ }^{25}$ Hastings, "The Council Came to Africa" 316.

${ }^{26}$ Bishop Vincent McCauley of Fort Portal, Uganda, for example, published and distributed English texts of the documents of Vatican II. Yet, when it comes to accessibility and familiarization with the documents of Vatican II, it would seem that they were "probably the least read and studied books in the presbyteries" (De Jong, Challenge of Vatican II in East Africa 33).

27 Alex B. Chima, "Africanising the Liturgy: Where Are We Twenty Years after Vatican II?" AFER 25 (1983) 280-91, at 291.

${ }^{28}$ Hurley, Vatican II 32. 


\section{Semper Idem: Resistance of Bishops and Priests}

A recurring theme in the assessment of the reception and implementation of Vatican II in Africa concerns the attitude of bishops and priests. De Jong lambasts African bishops and clergy for deliberately mounting resistance against orientation sessions and the implementation of Vatican II. The reasons he adduces for their formidable resistance stems from various factors. Steeped as they were in a legalistic, clericalist, and ultramontane theological upbringing, they showed little sympathy for indigenous religion and culture as useful sources of the inculturation of liturgy and catechetical reform. Nor were they enamored of the prospect of diminishment of clerical authority, social status, and living standard that a postconciliar ecclesiology seemed to indicate with the recognition of the important roles of the laity in the church. The reactions of African bishops and clergy to Vatican II seemed an exercise in surreptitious self-preservation and safeguarding of ecclesiastical and clerical privileges. ${ }^{29}$ This is De Jong's account; while it is too biased to form the basis of a general statement on the attitude and positions of African ecclesiastics and clergy vis-à-vis Vatican II, it merits further critical consideration as will become clear further on.

Notwithstanding the challenges posed by the illiteracy of ill-informed laity and the opposition of conservative and ill-prepared bishops and priests, evidence exists of credible attempts at propagating and implementing the directives and orientations of Vatican II in Africa. By way of illustration, three such attempts are noteworthy: Adrian Hastings's writings, African Ecclesial Review (AFER), and the Pastoral Institute of the Association of Member Episcopal Conferences of East Africa (AMECEA) in Gaba, Uganda.

\section{Adrian Hastings}

Available resources on the reception and implementation of Vatican II in Africa, particularly in East Africa, give considerable credit to the initiative, effort, and ingenuity of British Roman Catholic priest, theologian, and historian Adrian Hastings. "Hastings personally stoked the fires of Vatican II enthusiasm through his publication of a fortnightly bulletin." ${ }^{30}$ In response to the initiative of the AMECEA bishops to launch a program of postconciliar reeducation and reorientation for Kenya, Malawi, Tanzania, Uganda, and Zambia, Hastings produced critically acclaimed study guides and commentaries on the documents of the council pared down to the level of comprehension of missionary priests and religious, indigenous clergy, and lay people. Over a period of two years, this fortnightly bulletin,

29 De Jong, Challenge of Vatican II in East Africa 83-89.

${ }^{30}$ Gribble, Implementation of Vatican II in Eastern Africa 77; see also 155. 
"Post Vatican II: A Guide to the Documents of the Second Vatican Council," became the staple of conferences, seminars, workshops, meetings, and discussion groups on Vatican II of priests and religious, and, in some cases, of catechists and lay people in several parts of Africa and beyond. The opinion of one of the beneficiaries of Hastings's publication attests to its significant impact: "If there has been one factor that made Vatican II known, then that is it!" ${ }^{31}$ Regrettably, Hastings's initiative was short-lived.

\section{African Ecclesial Review (AFER)}

Hastings himself noted two other major factors that created "a real wave of pastoral renewal" in Africa following the conclusion of Vatican II, namely, the founding of the African Ecclesial Review (AFER) and the Pastoral Institute at Gaba. ${ }^{32}$ Regarding the former, "in addition to the Council documents and the authorized commentary by Hastings, the pastoral theological periodical, African Ecclesial Review (AFER), was an important factor in the process of assimilating Vatican II." 33 In the wake of Vatican II, AFER gained prominence as the leading journal of theology in English-speaking Africa.

Prior to and during the council, AFER published columns on happenings at Vatican II. In the first two decades following the council, some of the most critical and incisive analyses of conciliar documents, themes, and innovations appeared in AFER. Its publications would later include full texts of the conciliar documents and critical commentaries. Articles in AFER treated topics as varied as catechetics, sacraments, liturgy, interreligious dialogue, inculturation, ecumenism, and seminary formation in the context of the church in Africa.

Regrettably, the publications would fizzle out as the years went by, giving credence to Hastings's poignant observation about the fleeting lifespan of Vatican II's reception and implementation in Africa: "By the late 1970s the period of postconciliar innovation was well-nigh over. ... Clericalism at the top but congregationalism at the bottom proved the de facto compromise of the postconciliar African Church." 34

\section{AMECEA Pastoral Institute}

One institution that bears lasting testimony to the legacy of Vatican II for Africa is the AMECEA Pastoral Institute. The launch of this initiative responded to the need to communicate the vision, promote the teaching,

31 Quoted in De Jong, Challenge of Vatican II in East Africa 35.

32 Hastings, "The Council Came to Africa" 319.

33 De Jong, Challenge of Vatican II in East Africa 35.

34 Hastings, "The Council Came to Africa" 322. 
and implement the guidelines of Vatican II in all parts of the nascent African church. In the words of eyewitness Jean-Claude Lemay:

The decision of the AMECEA Bishops to launch a pastoral and catechetical institute was a deliberate attempt to meet the needs made more urgent by the context described above: the need to bring to grass-root level the doctrinal and pastoral renewal of Vatican II; the need to help pastoral workers to update themselves in the field of catechetical and pastoral work; the need for personal renewal. ${ }^{35}$

Lemay continues: "The academic input (of Gaba) would be geared towards updating and deepening the existing wealth of knowledge, in the light of the teaching of Vatican II." ${ }^{36}$

Concretely, this program included "a two-week period set aside for the study of the Vatican II documents." ${ }^{37}$ With time it expanded into a threeweek course on the documents of Vatican II. The profile of the initial participants in this program reflected "the mixity [sic] of the local church ... priest, religious, women and men, and laity, African and non-African." ${ }^{38}$ In addition to pastoral and catechetical training, for a few short years, the Pastoral Institute conducted experimentation in appropriately adapted and creative African liturgies in response to the inspiration and directives of Sacrosanctum concilium, the Constitution on the Sacred Liturgy.

As with the previous efforts considered in this essay, with the passing of the years, the impact of this institute as a prime facilitator and effective vehicle for the implementation of the directives and teaching of Vatican II would gradually diminish. Interestingly, this decline is attributable to the manifest conservatism within the church in Africa that resisted the orientation of Vatican II. Considering its status as a tool for implementing Vatican II, the Pastoral Institute owed its establishment and existence to the bishops of AMECEA. Curiously, however, the bishops took exception to the "liberal" and "progressive" direction of the Institute and adopted measures that not only curtailed the effectiveness of its programs, but would essentially engineer its gradual and eventual demise. ${ }^{39}$

\section{FIFTY YEARS ON: THE COUNCIL'S AFRICAN LEGACY}

The legacy of Vatican II is a matter of contention and debate among theologians in the world church. The same situation holds in Africa. Quite clearly, the perspectives of historians on Vatican II and Africa differ. These

35 Jean-Claude Lemay, "Gaba: A Story of Renewal" AFER 26 (1984) 22-31, at 23 .

36 Ibid. 24.

37 Ibid. 24, 25, 26; see also De Jong, Challenge of Vatican II in East Africa 41.

38 Lemay, "Gaba: A Story of Renewal" 24.

39 De Jong, The Challenge of Vatican II in East Africa 189; Gribble, The Implementation of Vatican II in Eastern Africa 159. 
perspectives are not straightforwardly descriptive, but thematic and fragmentary, and they contain multiple points of convergence and divergence. One major factor of interpretation lies in the fact that so far most of the accounts and interpretations are written by expatriates, reflecting interests, adopting methodology, and applying criteria that, far from being false, are radically partial. Unsurprisingly, favorable and flattering portrayals of the contributions of expatriate bishops and clergy dominate existing historical accounts. ${ }^{40}$ A comprehensive, critical, and scholarly account of Vatican II and Africa awaits realization-such an undertaking would avoid the pitfall of simply narrating Africa's presence and encounter with Vatican II in broad strokes. Conflicting perspectives aside, the positive impulses released by Vatican II for the church in Africa are beyond dispute:

For Bishops of the Catholic Church in East Africa, as for Bishops everywhere, the Council was not only an impressive assembly of the Universal Apostolic College; it was also a deep experience of learning, at times challenging and even disturbing, but also liberating and rewarding. ... For the leaders of the Church in East Africa, the sharing of the Council's experience became a priority. How could such renewal as they lived at Vatican II be brought to their people and in particular to their close collaborators in the ministry? ${ }^{41}$

Still, there are those, like Vincent Donovan, who contended that Vatican II's program for "young churches" produced a carbon copy of Eurocentric ecclesiology laden with all the trappings and flaws of the Western church. ${ }^{42}$ Donovan's unflattering characterization should not surprise us. As mentioned above, an "African" church could hardly be said to exist at the time of Vatican II.

Nevertheless, there are several useful areas for positively assessing the impact of Vatican II on the church in Africa in the past, at present, and for the future. Three such areas may be found distributed in the analyses of African theologians since Vatican II.

\section{Dining with the Devil}

In the missionary church, a key challenge of Christianity is how to fashion a constructive relationship with indigenous African religion. Despite

${ }^{40}$ Notably, De Jong, Challenge of Vatican II in East Africa; Gribble, Implementation of Vatican II in Eastern Africa. De Jong's bias is unmistakable in his claim that "Dutch missionaries and their colleagues from other countries were the reformers and renewers of the Church, while the African clergy in general remained dismissive of the renewals because of their clinging to conservative ecclesiological positions" (187).

41 Lemay, "Gaba: A Story of Renewal" 23.

42 Vincent J. Donovan, Christianity Rediscovered, 25th Anniversary Edition (1978; Maryknoll, NY: Orbis, 2003) 97, 131. 
deliberate attempts of Eurocentric missionaries and evangelists, Christianity could neither circumvent nor suppress the claims of indigenous religion in Africa. In general, "the encounter between Christianity and indigenous beliefs, rituals, and customs involved a massive and continuous process of interpretation and reassessment." 43 In many instances, ignorance and antagonism dominated the relationship and skewed the process, judging by the approach of missionaries obstinately commitment to their avowed mission to demonize, oppose, and eliminate all manifestations of indigenous religion and worship. Vatican II inaugurated a new approach that acknowledged the claims of "other religions" and attempted fresh interpretation and reassessment of interreligious encounter, while at the same time tenaciously asserting the superiority of Christianity and the preeminence of the Roman Catholic Church as the sacrament of salvation.

Nostra aetate, the Declaration on the Relation of the Church to NonChristian Religions, and Ad gentes, the Decree on the Church's Missionary Activity, provided the basis for adopting a fresh approach to non-Christian religions in the missionary context of Africa. In particular, Nostra aetate, as Emmanuel Ifesieh noted, "is in some ways one of the Council's most radical and far-reaching products, and it has many implications for the Church in Africa." 44

Although African religion-perhaps glibly subsumed under the category of people who seek God "in shadows and images" (Lumen gentium no. 16) - did not get a mention in these seminal documents, it is reasonable to argue that if one reads between the lines, Vatican II led to a shift in attitude vis-à-vis indigenous religion in Africa. ${ }^{45}$ The fundamental attitude of considering the latter solely and merely as preparatio evangelii remained dominant; but the council opened the way for the emergence of a marginally more sensitive approach that acknowledges goodness, truth, and holiness in other religions (Ad gentes nos. 3, 9, 11, 22; Nostra aetate no. 2; Sacrosanctum concilium nos. 37-40). ${ }^{46}$ Furthermore, the openness toward dialogue with, and respect for, indigenous African religion as contained in the analysis that exists in the corpus of African theology owes its origins to Vatican II. ${ }^{47}$

${ }^{43}$ Richard Gray, Christianity, the Papacy, and Mission in Africa (Maryknoll, NY: Orbis, 2012) 155.

${ }^{44}$ Emmanuel I. Ifesieh, "Vatican II and Traditional Religion," AFER 25 (1983) $230-36$, at 230 .

45 Ibid. 231.

${ }^{46}$ Eugene Hillman, Toward an African Christianity: Inculturation Applied (New York: Paulist, 1993) 38-40.

${ }^{47}$ Laurenti Magesa, "On Speaking Terms: African Religion and Christianity in Dialogue," in Reconciliation, Justice, and Peace: The Second African Synod, ed. Agbonkhianmeghe E. Orobator (Maryknoll, NY: Orbis, 2011) 25-36, at 26. 


\section{Inculturation-To Drum or Not to Drum}

In light of the preceding point, within the wider field of theological scholarship, a central topic that claims the attention of the postconciliar generation of African theologians concerns defining the meaning, delineating the scope, and regulating the application of the principle of inculturation. The primary aim of this process, as Eugene Hillman put it, is to determine "whether and to what extent Christian faith is supposed to bypass, negate or affirm the claims any culture has on the loyalty of its people." 48 As a theological initiative or project, we can rightly trace the origins of inculturation of the church to the teaching, guidelines, and direction of Vatican II. De Jong emphatically argues that "the foremost driving force for inculturation of the Church in this region [East Africa] consists in the new theological perceptions of Vatican II. ${ }^{, 49}$ The scope is continental. Yet, ironically, the direction of this project, at least in the initial phase of the implementation of the council, was not only attenuated but also strongly contested by a constellation of local factors and personalities.

De Jong also argues that the inculturation issuing from Vatican II was superficial. Not only does he regret this superficiality, but, as already mentioned, he also lays the blame squarely at the feet of conservative African episcopate and clergy. Credit for whatever simulacrum of postconciliar adaptation, Africanization, or inculturation that existed belonged to European bishops and clergy, not to-if I might paraphrase-their inferior, illiterate, and retrograde African counterparts bereft of theological imagination. ${ }^{50}$ This statement oversimplifies attitudes, facts, and processes in the church in Africa vis-à-vis Vatican II. It is largely biased, even though it identifies some exceptional cases of outright resistance. It is possible and necessary to perceive things in a different optic.

Hastings, who wields incontestable authority on this matter, contradicts De Jong's claims and provides a list of outstanding African ecclesial leaders, pioneers, and reformers inspired by the spirit of Vatican II, which De Jong's partial and biased account does not consider. The postconciliar movement of inculturation, reform, and renewal benefitted immensely from the activities of African ecclesial leaders who "were men of imaginative commitment, exuberance and charism." 51 The cast of postconciliar reformers included: Bishops Joseph Malula (Kinshasa, DRC), Christopher Mwoleka (Rulenge, Tanzania), Peter Sarpong (Kumasi, Ghana), Dennis Hurley (Durban, South

48 Hillman, Toward an African Christianity 29.

49 De Jong, Challenge of Vatican II in East Africa 187; see Gribble, Implementation of Vatican II in Eastern Africa 78-82.

50 De Jong, Challenge of Vatican II in East Africa 186-90; Gribble, Implementation of Vatican II in Eastern Africa 80-81.

51 Hastings, "The Council Came to Africa" 321. 
Africa), Patrick Kalilombe (Lilongwe, Malawi), Peter Dery (Wa, Ghana), and Emmanuel Milingo (Lusaka, Zambia). These ecclesial leaders understood postconciliar liturgical, sacramental, and theological inculturation as constitutive of the mission of the church in Africa.

Naturally, inculturation has created a rich terrain for evaluating the depth and extent of renewal generated by Vatican II in Africa. A much-debated and celebrated quintessence of this renewal was the introduction of African music and instrumentation into Catholic liturgy, the focal point of which was the African drum. While some would dismiss this as superficiality, ${ }^{52}$ others would perceive it as an initiative of immense symbolic value for the identity of the African church. "The drum was the great symbol of post-Vatican II liturgy - a symbol at once of cultural pluralism and popular participation, the arrival of an active laity, but still more the arrival of Africa in all its vibrant, populist, rhythmic vitality as a major reality within Catholicism." ${ }^{53}$

Taking account of the liturgical innovation inspired by Vatican II, especially via Sacrosanctum concilium, opinion on the progress in liturgical adaptation and inculturation in Africa has been consistently divided. Twenty years after Vatican II, Alex Chima made the following assessment: "Our liturgy is still far from having African 'flesh and blood,' as Vatican II, indirectly, says it should." ${ }^{54} \mathrm{He}$ concluded: "It seems we have not gone much further than the stage of relatively insignificant adaptations." 55 To recall De Jong's position, if Chima's analysis is correct, African bishops and priests are to blame for resisting postconciliar liturgical adaptation, whereas Dutch missionaries led the process of creative liturgical adaptation. Through De Jong's lens, one sees that it was only European ecclesiastics who presided over the presence of Africa at Vatican II and controlled the implementation of the teaching and directives of the council in some parts of Africa.

As shown above, however, it may be questioned whether De Jong's perspective does justice to the wider continental context. The situation in West and Central Africa could hardly be described as superficial, uninspiring, and lacking creativity or imagination. In these regions, it can be plausibly argued that Vatican II created a liturgical revolution in Africa of immense practical and pastoral significance. ${ }^{56}$ In Central Africa, for example, in the aftermath of Vatican II, legendary African ecclesiastic Cardinal Malula of Kinshasa

52 De Jong, Challenge of Vatican II in East Africa 181-85, 189.

53 Hastings, "The Council Came to Africa" 320.

54 Chima, "Africanising the Liturgy" 283.

55 Ibid. 290.

56 Hastings, "The Council Came to Africa" 320; for examples from West, Central, and East Africa, see Elochukwu E. Uzukwu, Worship as Body Language: Introduction to Christian Worship: An Orientation (Collegeville, MN: Liturgical, 1997) 270-317. 
initiated and led liturgical reforms that have lasted well into the 21st century. Undoubtedly, the impetus for this reform emanated from the inculturation movement triggered by Vatican II. A firsthand account from Nigeria in West Africa corroborates this claim: "Led by the themes of Vatican II, sensitivity to popular religion and culture and a commitment to inculturation made it possible to refashion liturgy, celebrating rites to be relevant and familiar, intelligible, and also emotionally stimulating. . . . Now there was permission for Africans to be Africans." ${ }^{27}$

In contemporary African theology and ecclesiology, inculturation represents an effective methodology of reflection, analysis, and praxis. ${ }^{58}$

\section{Ecclesial Pan-Africanism and Result-Oriented Particular Churches}

Another significant development that owes its origins to Vatican II is the awareness of African ecclesial leaders "that they belonged together, and should work in collaboration." ${ }^{59}$ The immediate outcome of this realization was the creation of continental and regional forums. "The collegiality experienced by the African bishops at Vatican II generated action for some form of permanent episcopal association, linking all African countries." 60 One example of this episcopal association is the Symposium of Episcopal Conferences of Africa and Madagascar (SECAM), founded in 1969. For several decades SECAM has served as the umbrella body for episcopal conferences on the continent in areas of evangelization, theological formation, social action, leadership development, and pastoral initiative.

The momentum for creating and sustaining pan-African movements inspired the establishment and development of fledgling regional and national bodies. An example of a highly effective regional body is Association of Member Episcopal Conferences in East Africa (AMECEA). AMECEA has developed an admirable profile in the African church in the area of regional ecclesiastical collaboration. Arguably, the most concrete and best achievement of AMECEA is its pioneering role in developing Small Christian Communities (SCCs) as a new way of being church ${ }^{61}$ and establishing a flagship higher education institution, the Catholic University of Eastern Africa (CUEA) in Nairobi, Kenya.

57 Jagoe, "Vatican II Comes to African" 550; see also Brian Hearne, "Conciliar Fellowship and the Local Church: A Catholic View from Africa," Ecumenical Review 29 (1977) 129-40, at 129.

58 See Laurenti Magesa, Anatomy of Inculturation: Transforming the Church in Africa (Maryknoll, NY: Orbis, 2004).

${ }^{59}$ Kalilombe, "Effect of the Council on World Catholicism: Africa" 311.

${ }^{60}$ Gribble, Implementation of Vatican II in Eastern Africa 164.

${ }^{61}$ See Joseph G. Healey and Jeanne Hinton, eds., Small Christian Communities Today: Capturing the New Moment (Maryknoll, NY: Orbis, 2005); Joseph Healey, 
Taken as a whole, these organs, forums, or platforms of ecclesiastical collaboration stand as structural, contextual, and appropriate expressions of the conciliar idea of "particular churches" (Ad gentes no. 22) ${ }^{62}$ Yet, reflecting on the five decades of ecclesial growth and development in Africa since Vatican II, I would see such optimistic characterization as contradicted by the intense centralization and concentration of the understanding of church in hierarchical structures of governance and control. At least in Africa, the promise or optimism of national and regional ecclesial structures as credible and vibrant loci of church and embodiment of catholicity has been fulfilled only partially. This, however, is in contrast to the growing prominence of national episcopal conferences in dealing with domestic socioeconomic and political issues since the 1980s. National conferences continue to be active in the public sphere. Examples of their zones of influence include facilitating political transitions, resolving social conflict, and negotiating peace and reconciliation in situations of armed violence. Such focus ad extra remains imbalanced in the absence of a commensurate focus ad intra on organizational and ecclesial matters affecting the Roman Catholic Church.

\section{CONCLUSION}

"The Church in Africa is greatly indebted to Pope John XXIII and to the Council that he convoked: the Second Vatican Council." 63 Thus began Ifesieh's article assessing two decades of Vatican II and its impact on traditional religion in Africa. His conclusion pays glowing tribute to the legacy of Vatican II for Christianity and the church in Africa: "Vatican II, by its openness to the God-given values in African traditional religion and culture, has initiated a new era for the Church in Africa, when Christianity will no longer appear as a foreign religion but as one that brings to fulfillment the deepest longings of African religiosity." ${ }^{64}$ Fifty years after the council, this positive and optimistic assessment bears the endorsement of several theologians and historians in Africa. Although numerically and theologically insignificant, Africa's dignified presence and participation at the council contributed to what historian of Vatican II Alberto Melloni designates as "multi-coloured universality" of the church. ${ }^{65}$

\footnotetext{
"Timeline in the History and Development of Small Christian Communities (SCCs) in Africa Especially Eastern Africa," http://www.smallchristiancommunities.org/ africa/africa-continent/107-timeline-in-the-history-and-development-of-small-christiancommunities-sccs-in-africa-especially-eastern-africa.html (accessed February 21, 2013).

62 Hearne, "Conciliar Fellowship and the Local Church" 133.

63 Ifesieh, "Vatican II and Traditional Religion" 230.

64 Ibid. 236.

65 Alberto Melloni, "The Second Vatican Council," Asian Horizons 6 (2012) $423-55$, at 431 .
} 
The currents of renewal and reform unleashed by the central affirmations of Vatican II continue to wax and wane against the retaining wall of legalism, clericalism, and conservatism. ${ }^{66}$ It goes without saying that all the accounts of the experience and reception of Vatican II in Africa focus on bishops as key players, primary implementers, authoritative interpreters, and incontestable guardians of the legacy of the council. There is nothing surprising about this approach in a church that continues to labor under clericalist and hierarchical tutelage and where the vast majority of the people of God minister, serve, and worship at the behest of the clergy. Clearly, certain features of the church in Africa continue to resist and hold out against the renewal and reforms inaugurated by Vatican II. Forms of this resurgent clericalism and conservatism exist in matters of sexual morality, control of liturgical development, gender discrimination, and the exercise of ecclesial authority.

As it should be clear to a keen observer of the history of Christianity in Africa, notwithstanding the multiple negative factors that have conditioned the reception and limited the implementation of Vatican in the African church, the impact of this ecclesial watershed limns more than just a trajectory of decline. Since what happened at Vatican II, studies in African Christianity provide incontrovertible evidence of demographic progress, theological creativity, and religious effervescence. ${ }^{67}$ In this sense, the Second Vatican Council is best understood in the currents of change and growth in African Christianity. While the council cannot be facilely credited for this growth, nevertheless it laid the foundation for the emergence and existence of a truly local African church and continues to inspire contextualized theological production.

Although the "letter" of the Second Vatican Council proved somewhat esoteric, indecipherable, and incomprehensible to the majority of Catholics on a largely nonliterate continent, the spirit of the council continues to animate, motivate, and support the demographic and theological flourishing of the African church. Adopting Adrian Hastings's words, we can sum up the theological and ecclesiological achievement of Vatican II in Africa as follows: "The Catholic Church of Africa of the 1980s is unthinkable without Vatican II and the many great endeavours which followed close upon it." 68 Hastings's claim holds true not only for the 1980s but also for present times.

${ }^{66}$ See Adrian Hastings, "Opting for Vatican II Plus," Journal of Theology for Southern Africa 41 (1982) 25-28, at 26.

${ }^{67}$ See Philip Jenkins, The Next Christendom: The Coming of Global Christianity (New York: Oxford University, 2002); John L. Allen Jr., The Future Church: How Ten Trends Are Revolutionizing the Catholic Church (New York: Doubleday, 2009); Kwame Bediako, Christianity in Africa: The Renewal of a Non-Western Religion (Maryknoll, NY: Orbis, 1995).

68 Hastings, "The Council Came to Africa" 322. 